\title{
TELEPON SELULER DAN PERGAULAN BEBAS REMAJA DI KABUPATEN MAMASA SULAWESI BARAT
}

\author{
A.NUR AISYAH RUSNALI \\ Institut Agama Islam Negeri Bone \\ rusnaliaisyah@gmail.com
}

\begin{abstract}
:
Information Technology, especially mobile telephone, has to develop its technology to cope with the need of the consumers. The purpose of this study to determine how cell phone use among teens from the point of view of teenage promiscuity and criminality in Mamasa, West Sulawesi. The method used is descriptive method with qualitative approach through direct observation of the object of research and interviews with informants related cases of promiscuity and criminality. Then analyzed using interactive model of Miles and Huberman. The results showed that the lack of control and the closeness to the elderly, causing teen cell phone users Mamasa addiction to technology. Teens using cell phones as a medium of communication to build closeness with others and a close friend. juvenile-related cases and crime free peregaulan manggunakan mobile phone without supervision and guidance of parents.
\end{abstract}

Keywords: cellular phone, promisquity.

\section{PENDAHULUAN}

Saat ini, kita hidup pada era informasi, sebuah era ketika media komunikasi telah menjadi pusat dari hampir semua yang kita lakukan. Alat untuk pengiriman transmisi dan menerima informasi selalu menempati tempat penting dalam aktivitas manusia. Dewasa ini teknologi komunikasi semakin berkembang dan terus maju. Telepon genggam atau yang lebih dikenal dengan sebutan HP (handphone) merupakan salah satu alat komunikasi yang sedang digemari oleh banyak orang. Hampir seluruh pelosok Indonesia sudah dapat menikmati manfaat dari telepon seluler. Sinyal telepon seluler sudah mampu menembus sampai ke daerah pelosok di Indonesia. Salah satunya kabupaten paling ujung dari Sulawesi barat, yaitu Mamasa.

Namun, seiring dengan perkembangan dan manfaatnya, telepon seluler di kabupaten Mamasa, juga membawa dampak negatif. Dapat dikatakan bahwa 
kejahatan melalui telepon seluler semakin marak terjadi, kuhususnya dikalangan remaja. Kejahatan yang seringkali terjadi diantaranya adalah penipuan, penculikan, hingga lebih jauh dapat berujung pada pergaulan bebas dan pelecehan seksual.

Determinsime teknologi adalah istilah, sering juga disebut dengan teori, yang dikemukakan oleh Marshall McLuhan pada tahun 1962 dalam tulisannya The Guttenberg Galaxy: The Making of Typographic Man. Ide dasar teori ini adalah bahwa perubahan yang terjadi pada berbagai macam cara berkomunikasi akan membentuk pula keberadaan manusia itu sendiri. Teknologi membentuk individu bagaimana cara berpikir, berperilaku dalam masyarakat, dan teknologi tersebut akhirnya mengarahkan manusia untuk bergerak dari satu abad teknologi ke abad teknologi yang lain

Dari hasil penelitian Dewinta (2012), yang berjudul Hubungan antara Karakteristik Individu dan Perilaku Komunikasi Penggunaan Telepon Genggam Siswa SMA Negeri 1 Mamasa. Hasil dari penelitian ini menunjukkan ada hubungan antara karakteristik individu dan perilaku komunikasi ramaja pengguna telepon seluler di Kabupaten Mamasa.

Nama Mamasa sebenarnya berasal dari "Mamase", artinya "tanah yang penuh kasih". Nama ini diberikan oleh nenek Dettumanan, sebab setiap datang berburuh ke lembah itu Dettumanan sangat mujur dan dengan mudah mendapatkan binatang buruan seperti anoa dan ikan di sungai tersebut. Sehingga beliau memberi nama "Lembang Mamase" artinya "lembah yang penuh kasih". Kabupaten Mamasa adalah hasil pemekaran Kabupaten Polewali Mamasa (Polmas) berdasarkan UU No.11 Tahun 2002 bersamaan dengan 22 Kabupaten dan Kota lainnya di era reformasi Indonesia pada tahun 2002.

kasus pergaulan bebas khususnya seks bebas dikalangan remaja dalam hal ini pelajar memang bukan hal yang asing lagi di Kabupaten Mamasa. Selanjutnya tindak kriminalitas seperti penganiayaan dan pencurian juga banyak terjadi dikalangan remaja kabupaten mamasa. Data Tindak Pidana SAT RESKRIM 
POLRES Mamasa menunjukkan bahwa, Pada tahun 2013 kepolisian mendapatkan 2 laporan terkait kasus pergaulan bebas remaja, 44 kasus penganiayaan dan 12 diantaranya adalah remaja, pencurian 17 kasus dan 5 diantaranya adalah remaja. Pada tahun 2014, kasus pergaulan bebas dan pelecehan seksual meningkat menjadi 8 kasus, sedangkan kasus penganiayaan berkurang menjadi 23 kasus, dan 7 diantaranya adalah remaja, kasus pencurian juga berkurang menjadi 13 kasus, namun 6 diantaranya adalah remaja.

Hal yang terjadi dalam kasus yang menimpa remaja diatas juga dapat membuktikan bahwa seseorang dapat terpengaruh dengan mudah melalui komunikasi menggunakan telepon seluler. Namun sangat disayangkan bahwa beberapa laporan kepolisian di atas menunjukkan bahwa penggunaan telepon seluler sebagai alat komunikasi dapat disalahgunakan dan merugikan pihak lain.

Interaksi yang berlangsung antara remaja ini dengan pria yang berujung pada pergaulan bebas, diawali dari interaksi pertemanan biasa. namun intensitas komunikasi dan interaksi melalui telepon seluler yang berlangsung intensif membuat korban menjadi percaya kepada pria yang baru dikenalnya tersebut dan kemudian bersedia mengikuti permintaan pria tersebut, yang tentu saja merugikan dirinya. Selain itu, penggunaan telepon seluler juga disalah gunakan sebagai media penipuan yang banyak dilakukan oleh remaja di kabupaten Mamasa

Bila penggunaan teknologi komunikasi di kalangan remaja dilakukan secara tepat guna, maka akan membawa dampak positif bagi perkembangan remaja. oleh karena itu peran orang tua sebagai pembimbing dan pengawas anak- anaknya dalam menggunakan telepn seluler sangatlah penting. Penelitian bertujuan untuk mengetahui bagaimana penggunaan telepon seluler dikalangan remaja dilihat dari sudut pandang pergaulan bebas dan tindak kriminalitas di Kbupaten Mamasa Sulawesi Barat. 


\section{Tujuan Penelitian}

Berdasarkan rumusan masalah di atas, maka penelitian ini dilaksanakan dengan tujuan :

1. Untuk mengetahui bagaimana penggunaan telepon seluler di kalangan remaja di kabupten Mamasa Sulawesi Barat.

2. Untuk mengetahui bagaimana penggunaan telepon selular berujung pada kasus pergaulan bebas remaja di Kbaupaten Mamasa Sulawesi Barat.

\section{METODE PENELITIAN}

Penelitian ini menggunakan tipe deskriptif kualitatif, di mana peneliti mendeskripsikan atau mengkonstruksi wawancara-wawancara mendalam terhadap subyek penelitian(Neuman,2013).Selanjutnya peneliti memberi makna pada realitas yang dikonstruksi subyek penelitian. Objek penelitian adalah remaja pengguna telepon seluler yang terkait kasus pergaulan bebas dan tindak kriminalitas di Kabupaten Mamasa. Pemilihan informan dalam penelitian ini menggunakan teknik purposive sampling, yang terdiri dari 6 orang informan internal, dan 4 orang informan eksternal. (Tabel 1).

Adapun metode pengumpulan data yang digunakan adalah observasi, wawancara yang mendalam pada setiap subyek penelitian yang bertujuan untuk memperoleh keterangan yang relevan mengenai komunikasi penggunaan telepon seluler dikalngan remaja Kabupaten Mamasa dan pengambilan data melalui internet. Data penelitian ini dianalisis menggunakan model Miles dan Huberman, yang meliputi: Pengumpulan Data, Reduksi Data, dan Penarikan Kesimpulan. 


\section{HASIL PENELITIAN DAN PEMBAHASAN}

\section{Jenis Pergaulan Bebas}

Berdasarkan wawancara dan observasi yang peneliti lakukan selama di tempat penelitian, kasus pergaulan bebas khususnya seks bebas dikalangan remaja dalam hal ini pelajar memang bukan hal yang asing lagi. Selanjutnya tindak kriminalitas seperti penganiayaan dan pencurian juga banyak terjadi dikalangan remaja kabupaten mamasa. Data Tindak Pidana SAT RESKRIM POLRES Mamasa menunjukkan bahwa, Pada tahun 2013 kepolisian mendapatkan 2 laporan terkait kasus pergaulan bebas remaja, 44 kasus penganiayaan dan 12 diantaranya adalah remaja, pencurian 17 kasus dan 5 diantaranya adalah remaja. Pada tahun 2014, kasus pergaulan bebas dan pelecehan seksual meningkat menjadi 8 kasus, sedangkan kasus penganiayaan berkurang menjadi 23 kasus, dan 7 diantaranya adalah remaja, kasus pencurian juga berkurang menjadi 13 kasus, namun 6 diantaranya adalah remaja.

\section{Penggunaan telepon seluler di kalangan remaja}

Dari hasil penelitian yang dilakukan, melalui metode wawancara menunjukkan bahwa, informan atau remaja pengguna telepon seluler di Kabupaten Mamasa telah mengalami kecanduan teknologi. Hal inilah yang dikemukakan oleh keenam informan remaja yang terkait kasus pergaulan bebas dan tindak kriminalitas. Mereka menggunakan telepon seluler hampir 24 jam setiap harinya. Hal ini merupakan sebuah konsekuensi logis, mengingat telepon seluler tidak memiliki batasan ruang dan waktu serta menawarkan banyak kemudahan yang lainnya. Seseorang dapat dengan mudah terhubung dengan orang lain tanpa harus dikhawatirkan oleh persoalan jarak geografis.

Telepon seluler mulai dapat diakses di Mamasa sekitar tahun 2007. Jika dilihat dari usia informan yang saat ini masih sekitar 13 sampai 19 tahun, maka saat itu mereka masih duduk dibangku Sekolah Dasar. Hal ini sesuai dengan pernyataan yang diungkapkan oleh informan pada saat wawancara. Saat diberi pertanyaan sejak kapan mereka mulai mengenal dan menggunakan Handphone, rata- rata menjawab pada saat mereka masih di bangku Sekolah Dasar. 
Telepon Seluler tidak hanya memberikan kemudahan berkomunikasi jarak jauh, namun memberikan banyak fitur menarik lainnya. Setidaknya hal inilah yang diungkapkan informan saat ditanya mengenai awal ketertarikan mereka menggunakan Handphone. Teknologi diciptakan manusia untuk membantu dan memudahkan manusia dalam kehidupan sehari- hari. Begitupula dengan telepon seluler yang diciptakan dengan tujuan untuk menghilangkan hambatan komunikasi berupa ruang dan waktu. Remaja di Kabupaten Mamasapun menggunakan telepon seluler dengan tujuan memudahkan komunikasi dengan keluarga dan teman- temannya.

Telepon seluler saat ini telah banyak menyajikan fitur- fitur menarik yang bisa diakses kapanpun dan dimanapun oleh penggunanya. Sejak jaringan telepon seluler mulai berfungsi dengan baik, hal ini memudahkan mereka untuk dapat mengakses internet dan menggunakan media sosial melalui telepon seluler. Namun fitur SMS dan telepon merupakan dua fitur utama yang paling sering digunakan oleh informan. Kemudian meyusul fitur lain, yakni internet, serta beberapa media sosial lainnya

Sebelum bertukar nomor ponsel, biasanya mereka sudah berkenalan lebih dulu. Entah itu melalui perantara teman ataukah keluarga. Meskipun belum pernah bertemu sebelumnya. Remaja Mamasa cenderung berani untuk memberikan ataupun bertukar nomor ponsel dengan orang yang baru mereka kenal. Bagi remaja, memiliki banyak nomor kontak di ponsel adalah hal yang menyenangkan. Dengan memiliki banyak nomor ponsel orang lain, remaja merasa telah memperluas pergaulannya dengan orang lain, khususnya teman dekatnya. rata- rata mereka tidak memiliki pertimbangan apapun saat orang lain meminta nomor ponselnya.

Kemudahan berkomunikasi dan fitur- fitur yang menarik yang diberikan oleh telepon seluler dapat menimbulkan kecanduan bagi penggunanya. Hal ini pula yang menjadikan handphone saat ini sebagai salah satu barang penting untuk dibawa. Setiap waktu dan kesempatan, setiap orang sibuk dengan handphone masing- masing. Tidak terkecuali remaja di Kabupaten Mamasa. Tujuan utama orang tua memberikan handphone pada anaknya khususnya yang masih remaja, 
selain mengikuti trend yakni untuk mempermudah mereka mengontrol keberadaan anaknya. Namun pada kenyataannya, hal tersebut justru semakin menjauhkan komunikasi antara orang tua dan anak, karena anak sudah sibuk sendiri dengan telepon seluler di tangannya. Pada saat berkomunikasi melalui telepon seluler, mengatur hal- hal terkait privasi atau keamanan merupakan hal yang sangat penting. Misalnya memberikan kata sandi atau kata kunci pada telepon seluler agar tidak mudah diakses oleh orang lain selain pemiliknya. Pada kenyataannya remaja Mamasa menggunakan pengaturan tersebut untuk menyembunyikan halhal bersifat pribadi dari orang tua mereka. Agar orang tua mereka tidak mengetahui bahwa mereka diam- diam menjalin kedekatan dengan pemuda atau pemudi lain

Remaja cenderung untuk menceritakan banyak hal kepada orang lain, apakah orang itu baru dikenal, ataupun sudah lama menjalin pertemanan. Kebiasaan remaja Mamasa sepulang sekolah, mereka sering menghabiskan waktu untuk mengobrol melalui telepon seluler, entah itu dengan teman sekolahnya ataukah teman dekatnya. Sekedar mengobrol tentang kejadian di sekolah ataukah membicarakan hal- hal yang bersifat pribadi.

\section{Penggunaan Teknologi Telepon Seluler dikalangan Remaja dilihat dari Sudut pandang Pergaulan Bebas}

Banyak keuntungan yang diperoleh dari teknologi komunikasi berupa Hand Phone/ telepon seluler, namun dibalik itu juga kerugian yang berdampak buruk terhadap perkembangan psikologis seseorang, terhadap kesehatan dan juga membuat aksi kejahatan serta praktik bisnis illegal semakin marak terjadi.

Kasus pergaulan bebas dan kriminalitas remaja di Kabupaten Mamasa merupakan salah satu bentuk disfungsi teknologi telepon seluler. Dari keenam informan yang terlibat kasus pergaulan bebas dan kriminalitas, memberikan pengakuan bahwa awal perkenalan mereka sampai akhirnya terjadi pergaulan bebas yang berujung pada laporan kepolisian berawal dari telepon seluler..

\section{PEMBAHASAN}

Penelitian ini menunjukkan bahwa, penggunaan telepon seluler dikalangan remaja Kabupaten Mamasa semakin memudahkan mereka untuk berkomunikasi dan 
menjalin hubungan dekat dengan orang lain. Dahulu Mamasa merupakan daerah yang terisolir, karena akses jalan menuju daerah tersebut yang cukup sulit. Namun setelah Mamasa berdiri sendiri sebagai kabupaten, Mamasa mulai menjadi daerah berkembang dengan masuknya berbagai teknologi komunikasi, seperti telepon seluler. teknologi tersebut diciptakan guna mempermudah kebutuhan manusia untuk berkomunikasi tanpa mengenal jarak dan waktu. Namun pada kenyataannya, justru kemudahan itu banyak disalah gunakan oleh manusia itu sendiri. Maka benarlah Firman Allah dalam Al Qur'an tentang fenomena ini “ Dan sesungguhnya Tuhanmu benar- benar mempunyai karunia yang besar (yang diberikan-Nya) kepada manusia, tetapi kebanyakan mereka tidak mensyukurinya" (Q.S As-Sajdah [32] : 9).

Hadirnya teknologi komunikasi berupa telepon seluler atau Hand Phone (HP) yang semakin pesat dan maju tidak dapat kita hindari. Tidak ada khalayak yang secara tegas menolak hadirnya teknologi yang dipuja oleh berbagai kalangan tersebut(Effendy onong,2005). Berbagai upaya dan cara yang kita lakukan untuk menolak hadirnya teknologi komunikasi tersebut malah justru akan semakin membuat kita pusing. Secara tidak langsung memang teknologi komunikasi membawa berbagai keuntungan bagi mereka penggunanya. Namun dibalik keuntungan yang menggiurkan tersebut ternyata terselip banyak kerugian yang menyebabkan dampak buruk bagi psikologis dan kesehatan penggunaan teknologi komunikasi itu sendiri(Devito,1997).

Masa remaja adalah masa dimana pengambilan keputusan mulai meningkat (Santrock, 2002). Remaja mengambil keputusan tentang masa depan, teman- teman yang akan dipilih dan seterusnya. Dalam beberapa tahun terakhir, para ahli telah mengembangkan riset mengenai peran kelekatan yang kokoh (secure attachment) serta konsep- konsep yang terkait seperti attachment dengan orang tua dalam perkembangan remaja(Santrock, 2002). Para ahli meyakini bahwa attachment dengan orang tua pada masa remaja dapat membantu remaja terkait perkembangan kompetensi sosial dan kesejahteraan sosial mereka; sebagaimana yang tercermin dalam ciri- ciri perkembangan harga diri, penyesuaian emosional, dan kesehatan fisik(kurniawati,2014). 
Hasil penelitian yang dilakukan ini melalui wawancara dan pengamatan dengan informan dengan usia remaja, baik remaja awal maupun informan pada masa remaja akhir meyatakan bahwa tingkat kedekatan mereka dengan anggota keluarga inti misalnya dengan orang tua, menjadi tidak dekat. Dengan ketidakdekatan informan dengan orang tua membuat mereka jarang sekali bahkan tidak pernah membahas mengenai aktivitas maupun teman dekat mereka selama terhubung melalui telepon seluler. Bahkan mereka cenderung sembunyisembunyi untuk berkomunikasi dengan teman dekat mereka. Hal ini juga berdampak pada orang tua yang relatif lebih banyak tidak mengetahui dengan siapa saja anak- anak mereka berteman dan berinteraksi. Selain itu, pertemanan mereka yang cenderung tidak mengatur hal- hal terkait privasi dengan memberikan nomor ponsel ke siapa saja tanpa tahu betul siapa orang tersebut. Waktu yang dihabiskan para remaja hanya untuk bercengkrama dengan teman yang baru dikenalnya dan bertukar nomor ponsel, jauh lebih banyak dan lebih intensif dibandingkan dengan waktu yang mereka gunakan untuk sekedar bercengkrama dengan orang tua maupun anggota keluarga mereka yang lain.

Telepon seluler merupakan teknologi komunikasi yang diciptakan oleh menusia untuk memudahkan proses pertukaran pesan. Telepon seluler diciptakan untuk megatasi hambatan berupa jarak dan waktu dalam proses komunikasi. Hal ini membenarkan teori digital Teori Digital yang menyatakan bahwa, teori digital merupakan sebuah konsep pemahaman dari perkembangan Zaman mengenai Teknologi dan Sains, dari semua yang bersifat manual menjadi otomatis ,dan dari semua yang bersifat rumit menjadi ringkas (littlejohn et al.,2009). Digital adalah sebuah metode yang Complex, dan fleksibel yang membuatnya menjadi sesuatu yang pokok dalam kehidupan manusia(Rachmah,2014).

Hasil penelitian yang dilakukan baik melalui metode wawancara maupun pengamatan menunjukkan bahwa kepercayaan dan relasi ternyata dapat dengan mudah dikembangkan melalui komunikasi intens dengan telepon seluler. Dari hasil wawancara yang dilakukan kepada beberapa informan membenarkan hal ini, mereka dengan mudah mengenal orang baru dalam rentang waktu yang relatif 
singkat. Mereka dapat menjadi sangat akrab sampai menjalin kedekatan dengan orang yang sesungguhnya belum pernah mereka kenal ataupun temui sebelumnya.

Penjelasan di atas, mampu menjelaskan pandangan Pierre Levy yang mengatakan bahwa media baru sebagai bentuk integrasi sosial, yeng merupakan gambaran media bukan dalam bentuk informasi, interaksi, atau penyebarannya, tetapi dalam bentuk ritual, atau bagaimana manusia menggunakan media sebagai cara menciptakan masyarakat.

Fenomena ini merujuk pada teori determinisme teknologi .Determinsime teknologi adalah istilah, sering juga disebut dengan teori, yang dikemukakan oleh Marshall McLuhan pada tahun 1962 dalam tulisannya The Guttenberg Galaxy: The Making of Typographic Man. Ide dasar teori ini adalah bahwa perubahan yang terjadi pada berbagai macam cara berkomunikasi akan membentuk pula keberadaan manusia itu sendiri. Teknologi membentuk individu bagaimana cara berpikir, berperilaku dalam masyarakat, dan teknologi tersebut akhirnya mengarahkan manusia untuk bergerak dari satu abad teknologi ke abad teknologi yang lain.

Relasi yang dibangun selama proses interaksi melalui telepon seluler merupakan proses yang aktif. Proses yang terjadi selama interaksi akan menghasilkan kesan dan pengalaman- pengalaman bagi setiap orang yang terlibat di dalamnya.

Dari hasil analisis data diketahui bahwa remaja di Kabupaten Mamasa menggunakan telepon seluler sebagai media komunikasi aktif untuk bersosialisasi dengan orang lain. Proses komunikasi yang intens menimbulkan kedekatan secara emosional antara remaja yang satu dan remaja yang lain dalam kurun waktu yang cukup singkat. Berangkat dari komunikasi yang intens tersebut, mereka kemudian berani untuk bertemu dan akhirnya berujung pada pergaulan bebas dan tindak kriminalitas.

Banyaknya kasus pergaulan bebas yang terjadi dikalangan remaja Mamasa, seolah tidak memberikan efek jera pada remaja lainnya. Menurut penuturan beberapa informan kepada peneliti melalui wawancara, hal tersebut sudah merupakan hal yang biasa terjadi bagi mereka. Bahkan mereka 
mengungkap satu fakta menarik bahwa, yang sampai pada pihak kepolisian itu belum seberapa. Karena masih banyak kasus serupa yang terjadi namun tidak diketahui oleh kepolisian, bahkan kedua orang tua remaja itu sendiri.

\section{PENUTUP}

Telepon seluler merupakan alat komunikasi yang diciptakan manusia untuk memudahkan proses komunikasi. Seiring dengan perkembangan teknologi, telepon selulerpun berkembang dari sekedar digunakan untuk menelepon dan mengirim pesan. Pengaruh penggunaan telepon seluler sangat besar di kalangan remaja kabupaten Mamasa. Disfungsi penggunaan telepon seluler memberikan dampak pada tingginya kasus pergaulan bebas dan kriminalitas remaja di kabupaten Mamasa. Dari enam kasus remaja yang terkait pergaulan bebas dan kriminalitas, semuanya diawali dari penyalahgunaan telepon seluler. Kurangnya pengawasan orang tua dan kurangnya pemahaman remaja mengenai fungsi utama dari telepon seluler menjadi salah satu faktor penyebab dari dampak negatif tersebut. Remaja Mamasa menggunakan telepon seluler sebagai media komunikasi aktif untuk menjalin kedekatan dengan orang lain. Dalam melakukan proses komunikasi menggunakan telepon seluler, Remaja di Mamasa cenderung sangat mudah memberikan nomor ponsel kepada siapa saja yang memintanya, dengan alasan untuk menambah teman dan memperluas pergaulan. Adapun saran yang direkomendasikan adalah pengguna telepon seluler seyogyanya dapat lebih arif dalam menggunakan dan membangun relasi yang sewajarnya dengan orang lain, serta lebih bijak dalam menyampaikan hal- hal terkait informasi personal dirinya. Hal ini tentunya menjadi sangat penting berkaitan dengan hubungan yang terjalin melalui komunikasi yang intens menggunakan telepon seluler, kepercayaan dan kewaspadaan menjadi landasan penting untuk melanjutkan dan mengembangkan relasi tersebut 


\section{DAFTAR PUSTAKA}

Devito J. A. (1997). Komunikasi Antar Manusia Edisi Kelima. Tangerang Selatan: Karisma Publishing Group.

Dewinta. (2012). Hubungan antara Karakteristik Individu dan Perilaku Komunikasi Penggunaan Telepon Genggam Siswa SMA Negeri 1 Mamasa. Skripsi . Makassar: Fakultas Ilmu Sosial dan Ilmu Politik Jurusan Ilmu Komunikasi Universitas Hasanuddin.

Effendy Onong Uchjana. (2005). Ilmu Komunikasi Teori dan Praktek, PT. Remaja Rosdakarya, Bandung.

Rachmah ida. (2014). Studi Media dan Kajian Budaya. Jakarta: Prenada Media Group.

Kurniawati, Nia Kania. (2014). Komunikasi Antarpribadi; Konsep dan Teori Dasar. Graha Ilmu, Yogyakarta.

Levy Pierre. (2001). Cyberculture. Saint Paul: U of Minnesota Press.

Littlejohn et al. (2009). Teori komunikasi. Jakarta: Penerbit Salemba.

McLuhan Marshall. (1962). The Gutenberg Galaxy: The Making of Typographic Man. Canada: University of Toronto Press.

Neuman W. Lawrence. (2013). Metodologi penelitian sosial: pendekatan kualitatif dan kuantitatif (edisi ketujuh). Jakarta: Indeks

Santrock J.W. (2002). Life- span development: perkembangan masa hidup. (edisi kelima). Jakarta: Erlangga. 